\title{
KARST SPRING MICROBIAL DIVERSITY DIFFERS ACROSS AN OXYGEN-SULPHIDE ECOCLINE AND REVEALS POTENTIAL FOR NOVEL TAXA DISCOVERY
}

\author{
PESTRA MIKROBNA DIVERZITETA VZDOLŽ EKOKLINE \\ KISIK-SULFID KRAŠKEGA IZVIRA ODKRIVA POTENCIAL \\ ZA OKRITJE NOVIH TAKSONOV
}

\author{
Janez MULEC ${ }^{1 *} \&$ Annette SUMMERS ENGEL ${ }^{2}$
}

\begin{abstract}
UDC 551.44:549.3(497.4), 551.44:579.8(497.4) Janez Mulec \& Annette Summers Engel: Karst spring microbial diversity differs across an oxygen-sulphide ecocline and reveals potential for novel taxa discovery

Strong geochemical gradients of dissolved oxygen and sulphide establish habitats where specialized bacterial and archaeal taxonomic groups occupy specific redox-sensitive niches, primarily based on metabolic and ecological requirements. In contrast, knowledge of microeukaryote diversity and their ecology in redox-stratified habitats is poor, as species-specific occupation of such geochemical gradients has not been well established. Here we assessed total microbial diversity from rRNA genes retrieved from two morphologically distinct microbial mats formed along an oxygen-sulphide gradient in the outflow channel from the Žveplenica sulphidic karst spring, Slovenia. Microbial mats contained diverse bacteria and archaea associated with chemolithoautotrophic and primary productivity, and overall microeukaryotic diversity was higher under oxygenated conditions. The oxygenated mats were comprised of undescribed and undifferentiated fungi, Annelida, Nematoda, Apicomplexa, and Gastrotricha, some being represented by novel lineages. Under anoxic conditions, diversity was dominated by Ciliophora, Nematoda, and Fungi-Ascomycota, also affiliated with novel lineages. Colonization of the distinct mat types related to ecological tolerance of specific geochemical conditions, and the associations between bacterial and archaeal diversity with distinct microeukaryotes may be related to grazing options and food web structure within the karst system.

Key words: karst, spring, sulphide, geochemical gradient, diversity, microeukaryotes.
\end{abstract}

\begin{abstract}
Izvleček UDK 551.44:549.3(497.4), 551.44:579.8(497.4) Janez Mulec \& Annette Summers: Pestra mikrobna diverziteta vzdolž ekokline kisik-sulfid kraškega izvira odkriva potencial za okritje novih taksonov

Izraziti geokemijski gradienti raztopljenega kisika in sulfida so osnova za habitate, kjer v odvisnosti od redoks potenciala, predvsem pa glede na metabolne in ekološke zahteve, specializirane bakterijske in arhejske taksonomske skupine zasedajo občutljive ekološke niše. Nasprotno pa je poznavanje diverzitete mikroevkariontov in njihove ekologije $\mathrm{v}$ habitatih, stratificiranih glede na redoks potencial, pomanjkljivo, saj vrstno specifične kolonizacije takšnih gradientnih okolij še nismo dobro proučili. Celotno mikrobno diverziteto smo ovrednotili na podlagi zaporedij rRNA genov, ki so bila pridobljena iz dveh morfološko različnih mikrobnih biofilmov, ki nastajata vzdolž gradienta kisik-sulfid v žveplenem kraškem izviru Žveplenica, Slovenija. Mikrobni biofilmi so vsebovali pestro združbo bakterij in arhej, ki jim pripisujemo kemolitoavtotrofen metabolizem s primarno produkcijo, celotna mikroevkariontska diverziteta pa je bila $\mathrm{v}$ oksigeniranih okoljskih razmerah višja. Oksigeniran biofilm so večinoma sestavljale še neopisane in nepoznane glive ter predstavniki skupin Annelida, Nematoda, Apicomplexa in Gastrotricha; nekatere izmed njih pripadajo celo novim linijam. V anoksičnih razmerah so prevladovali predstavniki skupin Ciliophora, Nematoda in Glive-Ascomycota, ki tudi pripadajo novim genetskim linijam. Kolonizacija različnih tipov biofilmov glede na ekološko toleranco specifičnih geokemijskih razmer ter povezava med bakterijsko in arhejsko diverziteto $\mathrm{z}$ značilnimi mikroevkariontskimi predstavniki sta lahko povezana $\mathrm{z}$ različnimi možnostmi prehranjevanja in s strukturo prehranjevalne verige v kraškem sistemu. Ključne besede: kras, izvir, sulfid, geokemijski gradient, diverziteta, mikroevkarionti.
\end{abstract}

\footnotetext{
${ }^{1}$ Karst Research Institute, Research Centre of the Slovenian Academy of Sciences and Arts, Titov trg 2, SI-6230 Postojna, Slovenia and UNESCO Chair on Karst Education, University of Nova Gorica, Glavni trg 8, SI-5271Vipava, Slovenia

${ }^{2}$ Department of Earth and Planetary Sciences, University of Tennessee, 1412 Circle Drive, Knoxville, TN 37996-1410, USA

*Corresponding author, e-mail: janez.mulec@guest.arnes.si, fax: + 38657001999
} 


\section{INTRODUCTION}

Geochemical gradients established by dissolved oxygen and reduced sulphur compounds, such as hydrogen sulphide, create an ecotonal transition between adjacent aquatic ecological systems where communities dependent on oxygenated conditions meet and interact with communities associated with anoxia (Kolasa \& Zalewski 1995; Behnke et al. 2006; Mulec et al. 2015). Diverse bacterial and archaeal communities commonly colonize oxygen-sulphide ecotones, with chemolithoautotrophic metabolism sustaining the ecosystems (Skirnisdottir et al. 2000; Takai et al. 2004; Mattes et al. 2013; Offre et al. 2013; Anderson et al. 2015; Hamilton et al. 2015). Higher eukaryotes thrive in these ecotone habitats, from deep-sea hydrothermal vents and other marine settings (Lopez-Garcia et al. 2001; Edgcomb et al. 2002; Lopez-Garcia et al. 2003; Behnke et al. 2010; Orsi et al. 2011; Holder et al. 2013) to continental karst aquifers and caves (Engel 2007; Por et al. 2013). But, microeukaryote diversity and ecology in these oxygen-sulphide ecotones are less understood, particularly those living in anoxic conditions (Fenchel \& Finlay 1995; Dawson \& Pace 2002; Edgcomb et al. 2002; Stoeck et al. 2003; Luo et al. 2005; Behnke et al. 2006; Epstein \& Lopez-Garcia 2008; Behnke et al. 2010; Creer \& Sinniger 2012; Parris et al. 2014; Wang et al. 2014; Oikonomou et al. 2015). In contrast, protist diversity in freshwater, continental habitats with oxygen gradients has been shown to be greater than previously considered (Oikonomou et al. 2015). The expectation is that microeukaryote diversity from these habitats is undersampled and novel diversity has yet to be discovered.

Aquatic cave and karst habitats have been investigated previously to uncover microeukaryotes diversity (Gittleson \& Hoover 1969; Walochnik \& Mulec 2009; Sigala-Regalado et al. 2011), with some efforts to characterize microeukaryotes communities from karst systems with sulphidic to oxic ecotones (Thompson \& Olson 1988; Sarbu 1990; Latella et al. 1999; Maggi et al. 2002; Nold et al. 2010a). In regions where caves are not accessible, or where there are limited wells and boreholes to sample subsurface water, continental sulphidic karst springs that discharge at the surface from fissured carbonate bedrock are ideal habitats to investigate microeukaryotes living in oxygen-sulphide ecotones in karst. This is because spring water contains nutrients and geochemical energy sourced from the subsurface (e.g., hydrogen sulphide), and the water also has the potential to flush out and carry subsurface microeukaryotes to the surface. Essentially, subsurface microeukaryotes can be sampled without needing to depend on wells, boreholes, or even caves to enter. Previous karst spring studies identify autochthonous microbial endokarst communities (AMEC) comprised of specific bacterial groups, such as members of Acidobacteria, Nitrospira, Gammaproteobacteria, and Deltaproteobacteria (Farnleitner et al. 2005; Pronk et al. 2009), where microeukaryotes are not been included. One of the distinguishing factors for AMEC is water residence time; longer residence times depend on the connectivity to the surface and flowpath tortuosity (Ford \& Williams 2007). Travel time can range from months to years (Griebler \& Lueders 2009), with longer times favouring the development of AMEC (Farnleitner et al. 2005; Brannen-Donnelly \& Engel 2015).

At the Žveplenica sulphidic karst spring in Slovenia, the discharging water is anoxic to suboxic and sulphidic, and abundant white, filamentous microbial mats occur at the spring orifice, previously identified as Epsilonproteobacteria (Rossmassler et al. 2012). Epigean copepods in different developmental stages, with many of them being alive (Mulec et al. 2015), are washed out from the spring orifice (Bryocamptus echinatus luenensis, Bryocamptus zschokkei, and Paracyclops fimbriatus). Wider representation of other eukaryotes would be expected for the whole karst system. Therefore, the objectives of our new study were to estimate the diversity of microeukaryotes from $18 \mathrm{~S}$ rRNA gene sequences, evaluate the spatial composition of microeukaryotes in anoxic and oxygenated subhabitats in the spring microbial mats, and discuss their ecology related to bacterial and archaeal taxonomy determined from 16S rRNA gene sequences. To our knowledge, this is one of the first assessments of microeukaryotes from sulphidic karst habitats by using molecular genetics methods, the other being of benthic microbial mats from a limestone sinkhole formed in Lake Huron, USA (Nold et al. 2010a; Nold et al. 2010b). 


\section{MATERIALS AND METHODS}

\section{SITE DESCRIPTION, WATER GEOCHEMISTRY, SAMPLING AND MICROBIAL MAT MORPHOLOGY}

The Žveplenica sulphidic karst spring $\left(46^{\circ} 03^{\prime} 59 \cdot 46^{\prime \prime} \mathrm{N}\right.$, $13^{\circ} 49^{\prime} 37 \cdot 81^{\prime \prime} \mathrm{E} ; 253 \mathrm{~m}$ a.s.l.) from coarse-grained, massive Upper Triassic dolomite (Mulec et al. 2015) discharged at $\sim 1.5$ to 2.0 litres per min from June 2008 to February 2011. A $1.5 \mathrm{~m}$ long channel is formed downstream of a $4-\mathrm{cm}$ diameter orifice of the spring before discharging into the Trebušica River. The groundwater geochemical composition indicates dissolution of dolomite (Zega et al. 2015).

From May 2009 to February 2011, the spring water temperature was monitored every $15 \mathrm{~min}$. Temperature varied seasonally, with the average being $10.5^{\circ} \mathrm{C}$ and ranging from $6.3^{\circ} \mathrm{C}$ to $13.9^{\circ} \mathrm{C}$. From August 2009 until February 2011, as reported in Mulec et al. (2015), average specific conductance was $418 \mu \mathrm{S} / \mathrm{cm}$ and $\mathrm{pH}$ was 7.58. Water at the spring orifice was actually anoxic $(0.13 \pm 0.11 \mathrm{mg} / \mathrm{ml}$ of dissolved oxygen), with $8.5 \mathrm{mg} / \mathrm{l}$ dissolved sulphide. Alkalinity was $223.2 \mathrm{mg} / \mathrm{l}$ (expressed as $\mathrm{CaCO}_{3}$ ), and there were no $\mathrm{NO}_{3}^{-}$and low concentrations of $\mathrm{PO}_{4}^{3-}(0.02 \mathrm{mg} / \mathrm{l}), \mathrm{SO}_{4}^{2-}(9.00 \mathrm{mg} / \mathrm{l})$ and $\mathrm{Cl}^{-}$ $(10.00 \mathrm{mg} / \mathrm{l})$.

Sparse white filaments were attached to sediment in the orifice, and filaments of different lengths extended downstream where they coalesced to form a grey microbial mat in the stream channel. Long filaments detached, floated downstream, then sank in the Trebušica River. After heavy rain precipitation, especially in spring and autumn, the spring orifice would be flooded by the river, and filaments would be completely stripped from the orifice and stream channel. Downstream, dissolved oxygen concentrations increased and dissolved sulphide concentrations decreased to undetectable concentrations beyond the sampled grey mat (Mulec et al. 2015). Approximately $5 \mathrm{~g}$ of white microbial filaments were collected from the orifice and about the same quantity of grey mats were collected $50 \mathrm{~cm}$ downstream from the orifice in June 2008, in conjunction with another study (Rossmassler et al. 2012).

\section{DNA EXTRACTION, PCR AMPLIFICATION, CLONING, AND SEQUENCING}

Total environmental DNA was extracted in triplicate using methods as previously described (Engel et al. 2003). Approximately $0.5 \mathrm{~g}$ of microbial mat was aseptically collected and transferred into DNA extraction buffer $(10 \mathrm{mM}$ Tris- $\mathrm{HCl}, 100 \mathrm{mM}$ EDTA, 2\% sodium dodecyl sulphate). The extraction protocol was similar to the commercially available Purgene DNA extraction kits (Gentra Systems, USA), with some modifications. $9 \mu \mathrm{l}$ of proteinase $\mathrm{K}(20 \mathrm{mg} / \mathrm{ml})$ was added to DNA extraction buffer prior to digestion. A freeze-thaw series (three times at $-80^{\circ} \mathrm{C}$ to $65^{\circ} \mathrm{C}$ ) was used to disrupt the mat structure. Samples were further incubated at $55^{\circ} \mathrm{C}$ overnight to digest cellular material and RNase was added and incubated at $37^{\circ} \mathrm{C}$ for up to $1 \mathrm{~h}$. Proteins were precipitated in $10 \mathrm{M}$ ammonium acetate. Nucleic acids were precipitated in isopropanol overnight at $-20^{\circ} \mathrm{C}$ and finally washed in 70\% ethanol. DNA yield was assessed from TBE gel electrophoresis with ethidium bromide staining and spectrophotometrically using standard absorbance at $260 \mathrm{~nm}$ and $280 \mathrm{~nm}$ on a NanoDrop ND1000 UV/Vis spectrophotometer (NanoDrop Technologies, USA).

All PCR amplification reactions were done with 5PRIME Perfect Taq polymerase and a MJ Research thermal cycler. Bacterial 16S rRNA gene sequences were amplified using the forward primer 8F (5'-AGA GTT TGA TCC TGG CTC AG-3') and reverse primer 1510R (5'-GGT TAC CTT GTT ACG ACT T-3') (Lane 1991). PCR conditions for bacterial-specific primers were: initial denaturation at $94^{\circ} \mathrm{C}$ for $4 \mathrm{~min} ; 30$ cycles of denaturation at $94^{\circ} \mathrm{C}$ for $1 \mathrm{~min}$, annealing for $1 \mathrm{~min}$ at $47^{\circ} \mathrm{C}$ for white mat or $50^{\circ} \mathrm{C}$ for grey mat and elongation at $72^{\circ} \mathrm{C}$ for $1.5 \mathrm{~min}$; final extension at $72^{\circ} \mathrm{C}$ for $20 \mathrm{~min}$. Annealing temperatures for each sample type were optimized from temperature-gradient tests to obtain the highest amplification product yield and from electrophoresis gel verification of no extra banding. Archaeal 16S rRNA gene sequences were amplified by using the forward primer UA571F ( $5^{\prime}$-GCY TAA AGS RIC CGT AGC-3') and reverse primer UA1204R ( $5^{\prime}$-TTM GGG GCA TRC IKA CCT -3') (Baker \& Cowan 2004). PCR conditions for both mat types using archaeal-specific primers were from Baker et al. (2003). For amplification of eukaryotic $18 \mathrm{~S}$ rRNA, we used protocols and primer pairing from Zuendorf et al. (2006) to obtain gene fragments ranging up to $1800 \mathrm{bp}$ in length. The J1 primer set used the forward primer EukA (5'-AAC CTG GTT GAT CCT GCC AGT-3') (Diez et al. 2001) and reverse primer U1517R (5'-ACG GCT ACC TTG TTA CGA CTT-3'). The M2 primer set used the EukA forward primer and U1391R reverse primer (5'-GGG CGG TGT GTA CAA RGR$3^{\prime}$ ) (Zuendorf et al. 2006). PCR amplification for both mat types was done with an initial hot start $(15 \mathrm{~min}$ at $95^{\circ} \mathrm{C}$ ) followed by 30 cycles of denaturing at $95^{\circ} \mathrm{C}$ for 45 $\mathrm{sec}$, annealing for $1 \mathrm{~min}$ at $55^{\circ} \mathrm{C}$ for the J1 primer set, or $56^{\circ} \mathrm{C}$ for primer set $\mathrm{M} 2$, and extension at $72^{\circ} \mathrm{C}$ for 2.5 
min. A final extension was done at $72^{\circ} \mathrm{C}$ for $7 \mathrm{~min}$. Each reaction contained $\sim 20 \mathrm{ng}$ of template DNA, $0.8 \mu \mathrm{M}$ of each primer, $1.6 \mathrm{mM}$ dNTP, $1.6 \mathrm{mM} \mathrm{MgCl} 2,1 \times \mathrm{PCR}$ buffer, $0.16 \mathrm{mg} / \mathrm{ml} \mathrm{BSA}$, and 1 unit of Taq polymerase for the J1 primers and 2 units for the M2 primers.

Amplified PCR products using the different primer sets were purified using a TAE low-melt agarose gel and a Wizard PCR Preps DNA Purification System (Promega Corporation, Madison, Wisconsin, USA). PCR products were cloned separately for each primer set using Invitrogen TA Cloning kits (Carlsbad, California, USA), following manufacturer instructions. Clones having the correct size insert for each library were confirmed by M13-primer PCR amplification, as described previously (Porter et al. 2009), and screened using TBE electrophoresis gels and ethidium bromide staining. Clones were sequenced at the University of Washington, High-throughput Genomics Unit, using capillary sequencers (Sanger sequencing) and M13 primers and the internal primer $907 \mathrm{R}$ for $16 \mathrm{~S}$ rRNA genes (5'-CCG TCA ATT CMT TTR AGT TT-3') and internal primer 582F (5'-CGGTAATTCCAGCTC-3') for $18 \mathrm{~S}$ rRNA genes (Elwood et al. 1985).

\section{CLONE LIBRARIES AND PHYLOGENETIC ANALYSES}

rRNA gene sequences were assembled using ContigExpress from Vector NTI Advance ${ }^{\circledast}$ (Invitrogen Corp., USA), then screened for the presence of chimera by using the computer programs UCHIME (Edgar et al. 2011) and DECIPHER (http://DECIPHER.cee.wisc. edu) (Wright et al. 2012). Chimeras were also checked manually and $\sim 10 \%$ of all the $16 \mathrm{~S}$ rRNA gene sequences were removed. Six $18 \mathrm{~S}$ rRNA gene sequences were removed due to poor alignment. Together, 131 bacterial, 186 archaeal, and 156 eukaryotic sequences were analysed. Retained 16S and 18S rRNA sequences were analysed by using NCBI BLAST (Camacho et al. 2009), the RDP (version 11) Classifier (Cole et al. 2014) and the SILVANGS analysis pipeline (SILVA SSU and LSU databases 119.1) (Quast et al. 2013) to determine sequence taxonomic affiliations and to obtain the closest gene sequence matches. Eukaryotic taxonomy was done according to Adl et al. (2005). For sequences, single phylotype clades were made when sequences had $97 \%$ or greater sequence identity. For $16 \mathrm{~S}$ rRNA genes for both bacterial and archaeal clone libraries, multiple sequence alignments were performed using Greengenes workbench (DeSantis et al. 2006). Multiple sequence alignments of $18 \mathrm{~S}$ rDNA libraries were performed using SILVA for major known eukaryotic phyla (Pruesse et al. 2007; Pruesse et al. 2012). Only conserved and unambiguously aligned positions were used in the subsequent phylogenetic analyses. All sequences were compiled and evolutionary analyses were conducted in MEGA 6.0 (Tamura et al. 2013). Rarefaction analyses and diversity indices were calculated with the Mothur computer software (Schloss et al. 2009).

\section{NUCLEOTIDE SEQUENCE ACCESSION NUMBERS}

rRNA gene sequences reported in this study were deposited in the GenBank database, for Bacteria and Archaea under the accession numbers KT072259 to KT072575, and for the eukaryotic sequences under the accession numbers KT072097 to KT072258.

\section{RESULTS}

\section{S rRNA GENE SEQUENCE DIVERSITY} AT THE SULPHIDIC TO OXIC ECOCLINE

Retrieved bacterial sequences from both microbial mat types were affiliated with putative sulphur-metabolizing or chemolithoautotrophic taxa within the Proteobacteria, notably belonging to the Gamma-, Beta-, and Epsilonproteobacteria (Figs. 1 and 2). Gammaproteobacteria belonging to the genus Thiothrix represented $\sim 23.6 \%$ of the relative abundances for both white and grey mat communities, and Betaproteobacteria dominated the grey mat sample in the aerobic portion of the stream $(29.1 \%$ relative abundance). Genera within the Betaproteobacteria included the Azospira, Iodobacter, Georgfuchsia,
Pelomonas, Rhodoferax, Undibacterium, and Thiobacillus. Epsilonproteobacteria were more prevalent in the white mat (15.8\% relative abundance in the community) compared to the grey mat (12.7\% relative abundance), with genera belonging to the Dehalospirillum, Sulfuricurvum, and Sulfurovum. The white mat in the anoxic portion of the stream also had sequences affiliated with the Chloroflexi, within the Anaerolineaceae (7.9\% of the community), and the Deltaproteobacteria (5.3\%) affiliated with the genus Desulfocapsa and Geobacter. Bacteroidetes, affiliated with the genera Flavobacterium, Haliscomenobacter, Gilvibacter, and Paludibacter, comprised $26.3 \%$ of the white mat community and $20.0 \%$ of the grey mat com- 
munity. Representation from other taxonomic groups included the Alphaproteobacteria, Firmicutes, Planctomycetes, Lentisphaerae, and the Candidate Division SR1. Members of the Candidate Division SR1 comprised
$11.8 \%$ of the white mat community and $5.5 \%$ of the grey mat community and were closely related to an environmental clone retrieved from a meromictic lake in France [FJ482219] (Borrel et al. 2010).

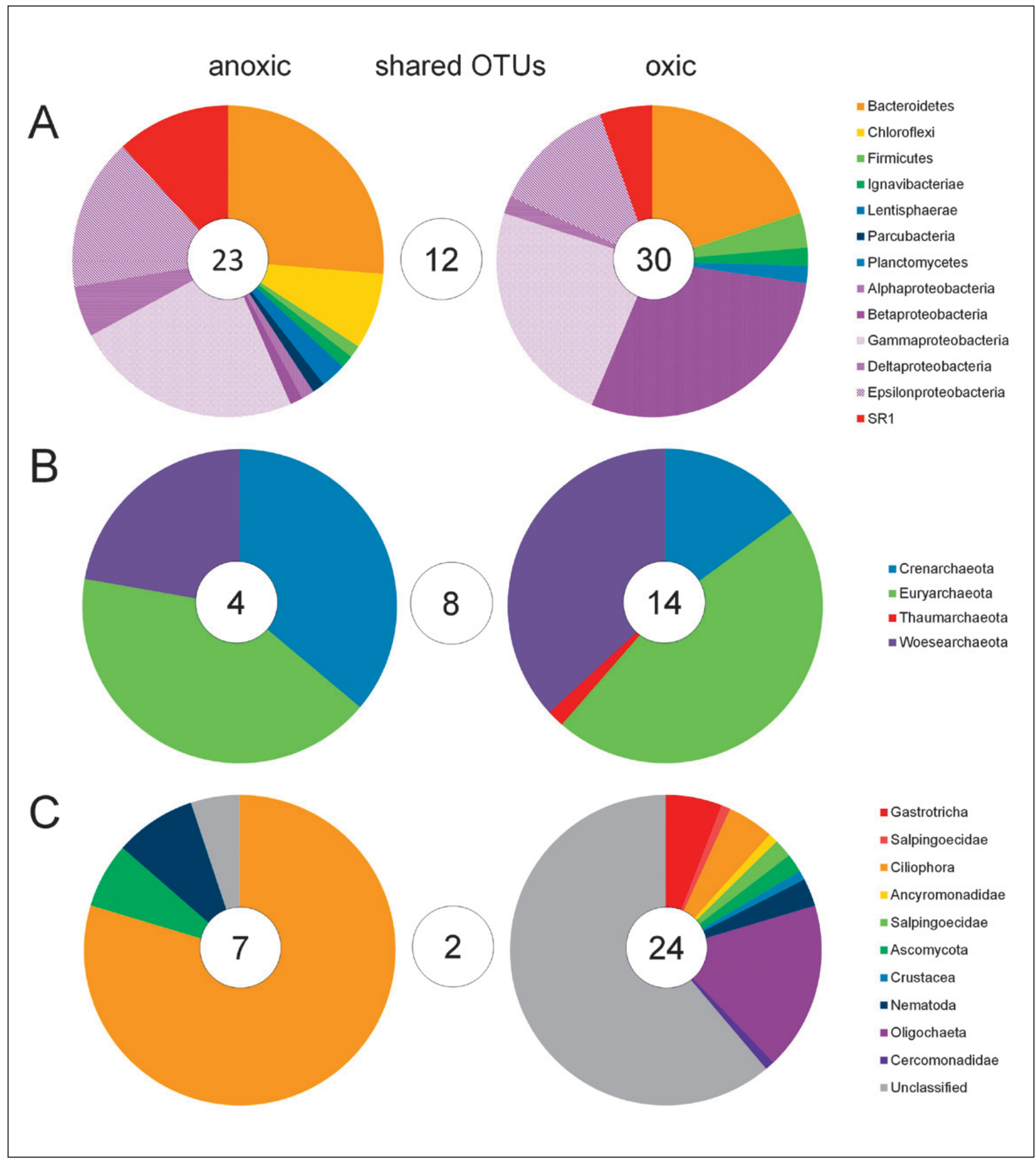

Fig. 1: Taxonomic distribution of $16 S$ rDNA OTU-based phylotypes of (A) bacteria, (B) archaea, and (C) eukaryotic $18 \mathrm{~S}$ rDNA retrieved from upstream anoxic and downstream oxygenated microbial mats. Taxonomic assignments were based on a minimum of $97 \%$ sequence identities. The number of unique OTUs per sample are noted, and the number of shared OTUs between the mat types are presented (distance 0.03). 
Among the Archaea, diversity was lower from the white mats in the anoxic part of the channel (Figs. 1 and 3). And the majority of clones were affiliated with Euryarchaeota, with $41.7 \%$ in the white mat and $46.5 \%$ in the grey mat community. The relative proportions of clones belonging to the orders Methanomicrobiales, Halobacteriales, and Thermoplasmatales were similar for both mats. The relative abundances of Crenarchaeota

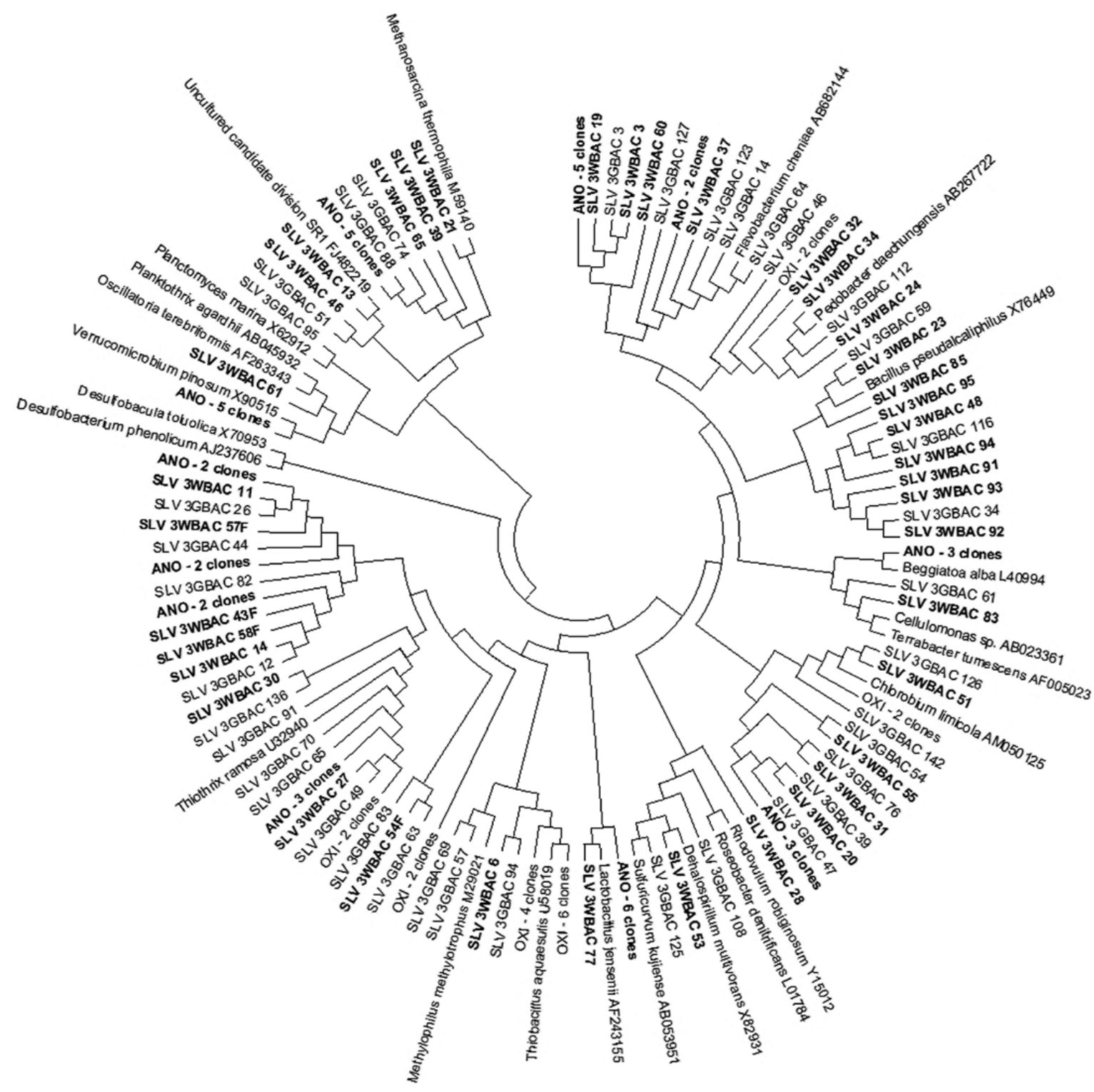

Fig. 2: Molecular phylogenetic analysis of bacterial $16 \mathrm{~S}$ rDNA by Maximum likelihood method. Clones for the white (W, also labelled in bold) and grey $(G)$ mats are included, and redox conditions for the mats are noted if more than one clone formed a clade, ANO for anoxic mats and OXI for oxic mats. The evolutionary history was inferred by using the Maximum Likelihood method based on the Kimura 2-parameter model (Kimura, 1980). The bootstrap consensus tree inferred from 100 replicates (Felsenstein, 1985) is taken to represent the evolutionary history of the taxa analysed (Felsenstein, 1985). Branches corresponding to partitions reproduced in less than 50\% bootstrap replicates are collapsed. Initial tree(s) for the heuristic search were obtained by applying the neighbour joining method to a matrix of pairwise distances estimated using the Maximum Composite Likelihood (MCL) approach. The analysis involved 154 nucleotide sequences. All positions with less than 95\% site coverage were eliminated. That is, fewer than 5\% alignment gaps, missing data, and ambiguous bases were allowed at any position. There were a total of 113 positions in the final dataset. 
were greater in the white mat $(36.1 \%$ relative abundance in the community) compared to the aerobic part of the channel (15\% relative abundance), but the abundances of sequences affiliated with Woesearchaeota were greater in the grey mat (36.8\% of the community) compared to the white mat (22.2\% of the community).

Although the observed species richness for both bacterial and archaeal libraries was underestimated ac-

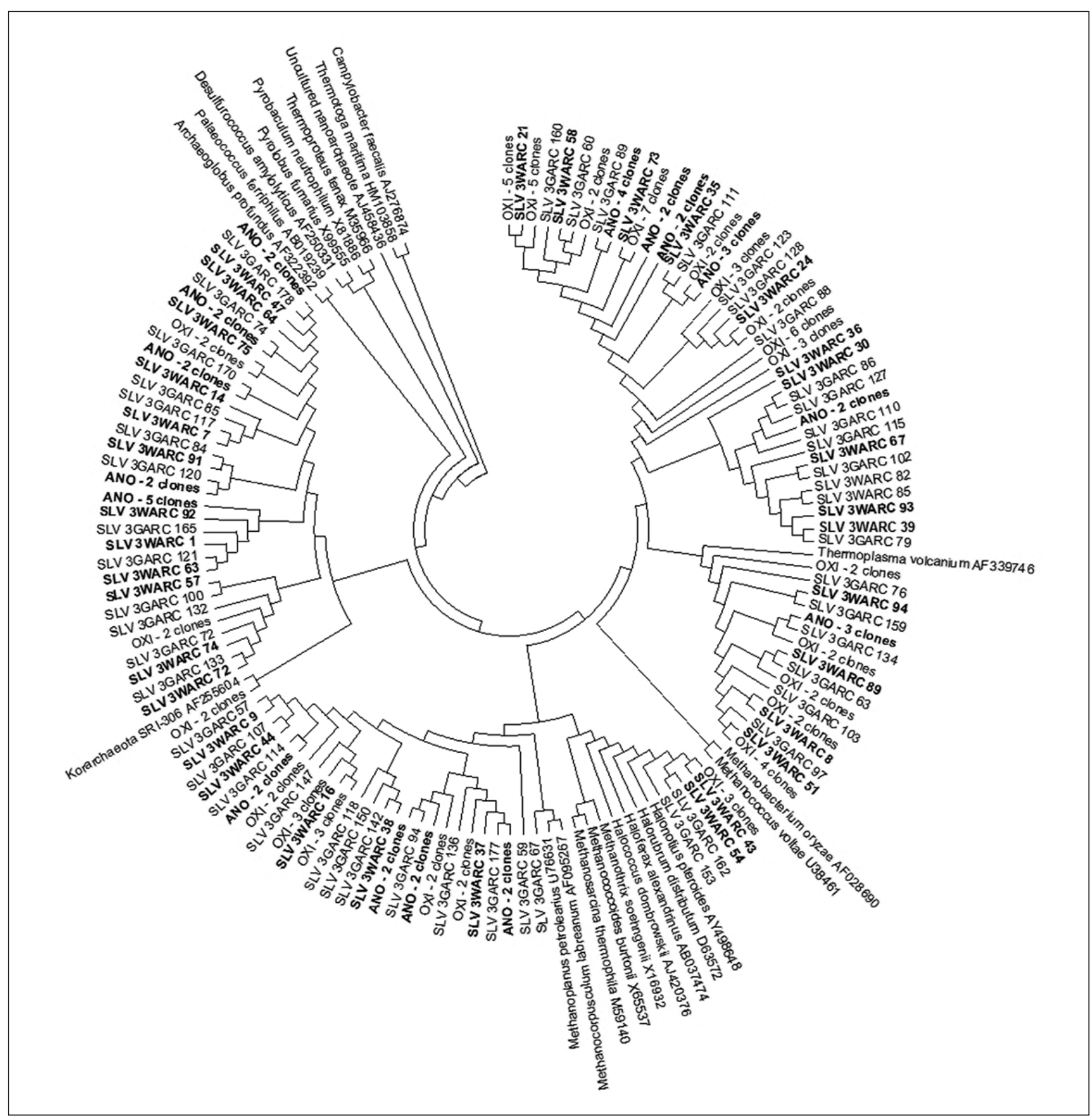

Fig. 3: Molecular phylogenetic analysis of archaeal $16 \mathrm{~S}$ rDNA by Maximum likelihood method. Clones for the white (W, also labelled in bold) and grey $(G)$ mats are included, and redox conditions for the mats are noted if more than one clone formed a clade, ANO for anoxic mats and OXI for oxic mats. The evolutionary history was inferred by using the Maximum Likelihood method based on the Kimura 2-parameter model (Kimura, 1980). The bootstrap consensus tree inferred from 100 replicates (Felsenstein, 1985) is taken to represent the evolutionary history of the taxa analysed (Felsenstein, 1985). Branches corresponding to partitions reproduced in less than 50\% bootstrap replicates are collapsed. Initial tree(s) for the heuristic search were obtained by applying the neighbour joining method to a matrix of pairwise distances estimated using the Maximum Composite Likelihood (MCL) approach. The analysis involved 208 nucleotide sequences. All positions with less than $95 \%$ site coverage were eliminated. That is, fewer than $5 \%$ alignment gaps, missing data, and ambiguous bases were allowed at any position. 


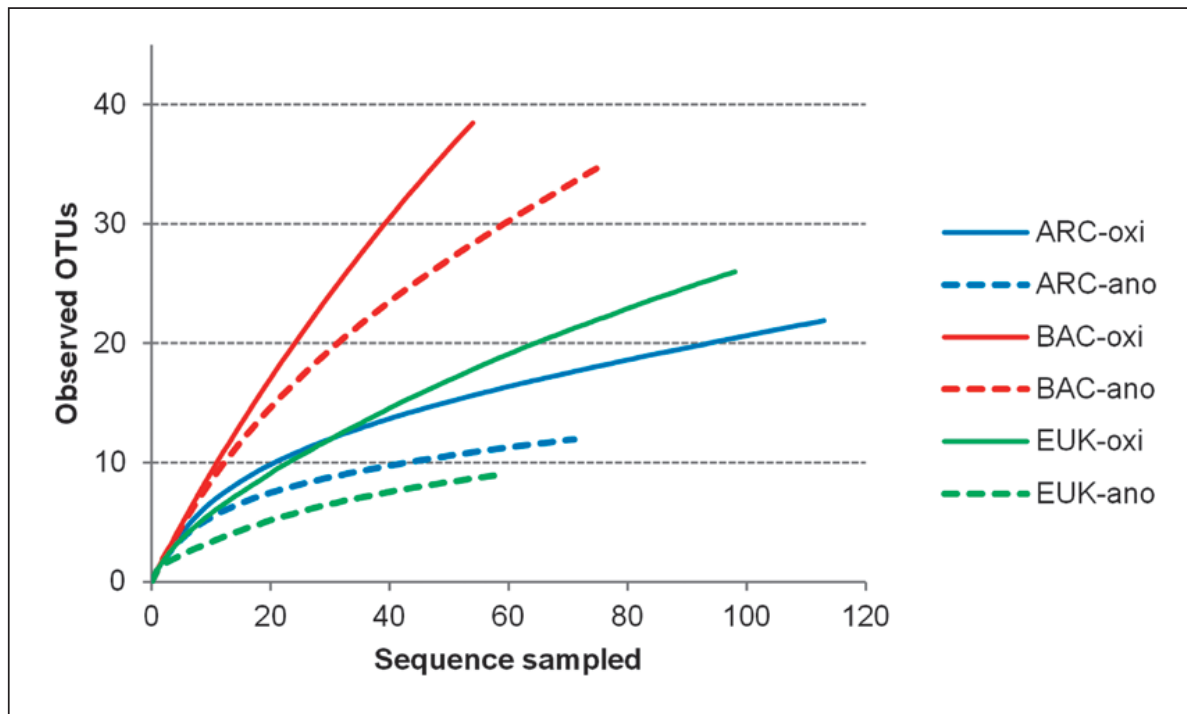

Fig. 4: Sampling saturation profile for archaea (ARC), bacteria (BAC) and eukarya (EUK) from white mat under anoxic condition (ano) and grey mat exposed to oxygenated conditions (oxi). Phylotypes were defined to encompass clones that exhibited at least $97 \%$ sequence similarity.

cording to rarefaction curves (Fig. 4), and more clones would need to be screened to retrieve the full diversity, approximately one third of bacterial and archaeal phylotypes overlapped between the two mat types (Fig. 1). Specifically, 12 bacterial OTUs were shared between the white mats upstream (anoxic) and grey mats downstream (oxic), and eight archaeal OTUs were shared between the anoxic and oxic subhabitats.

\section{S rRNA GENE SEQUENCE DIVERSITY AT THE SULPHIDIC TO OXIC ECOCLINE}

A double set of primers was essential to reveal wider eukaryotic diversity, although much greater diversity than was retrieved likely exists because the total number of clones screened in this study was insufficient to uncover total richness based on rarefaction curves (Fig. 4). Few of the retrieved $18 \mathrm{~S}$ rRNA gene sequences were related to previously known taxa at $>97 \%$ sequence similarity according to BLAST and SILVA ${ }_{\mathrm{NGS}}$ analysis pipeline (Fig. 5), specifically for the downstream mats that had $61.2 \%$ unclassifiable sequences (Fig. 1). However, among the groups with robust taxonomic assignments, eukaryotic groups from the upstream white mats were affiliated with the Ciliophora (79.7\% of the sequences in the community), which includes the subgroups of ciliates, dinoflagellates, and apicomplexans. The order Hymenostomatida represented most of the ciliophores, at $72.9 \%$ of the total eukaryotic sequences from the white mats. The closest relative was the ciliate Glaucomides spp. (96-99\% sequence similarity for all matching clones). Nematoda and Ascomycota comprised the remaining $15.3 \%$ of sequences from the white mats. The closest nematode relative was Rhabdolaimus sp. (9799\% sequence similarity), which have been previously retrieved from microbial mats on lava tube cave walls from Hawai'i (GenBank Accession no. EF032796), and are commonly found in soil and springs, including those with low oxygen concentrations (Tahseen 2012).

From the downstream grey mats in oxygenated water, which were more diverse at the level of OTUs than the white mats (Fig. 1), more than $80 \%$ of the sequences were affiliated with the Fungi/Metazoa group (Opisthokonta). Fungi represented $44 \%$ of the sequences, with most being related to the early diverging fungal lineage Cochlonemataceae, and specifically to the genus Cochlonema (87-90\% sequence similarity). Among the metazoans (Holozoa), 54\% of the sequences were affiliated with the Naididae (sludge worms), 23\% with the Nematoda (round worms), $17 \%$ to the Chaetonotidae (gastrotrichs), and 3\% each to the Maxillopoda (copepods) and Macrobiotidae (tardigrades). The nematode sequences retrieved from the grey mats were related to an unnamed species previously identified from Lake Huron (GenBank accession no. EU910601) (Nold et al. 2010b). The majority of the Naididae were annelids belonging to the Tubificinia, and were related to the genus Slavina (98-99\% sequence identity). Among the Chaetonotidae, most of the sequences were related to the genus Chaetonotus (90-99\% sequence similarity). Copepod sequences were related to the genus Bryocamptus; this group was identified previously from the spring microbial mats (Mulec et al. 2015). The remainder of the community was comprised of Cercozoa and Alveolata, at $\sim 5 \%$ each, and sequences affiliated with the Stramenopiles, Amoebozoa, Apusozoa, and Euglenozoa represented $3 \%$ or less of the community. Only two OTU-based phylotypes were shared between the two mat types (Fig. 1). 


\section{DISCUSSION}

According to niche theory, ecological tolerance influences wide or narrow distributions of organisms within a habitat and across habitats (Heino \& Soininen 2006; Soininen \& Heino 2007; Behnke et al. 2010; Orsi et al. 2011). Because some novel aquatic microeukaryotic lineages occupy distinct habitat types, the suggestion has been that microeukaryotes may have high degrees of en- demism (Dawson \& Pace 2002; Edgcomb et al. 2002; Lopez-Garcia et al. 2003; Stoeck \& Epstein 2003; Bass et al. 2007; Boenigk et al. 2007; Orsi et al. 2011). Indeed, finding microeukaryotes living in specific habitat conditions continues to challenge global dispersal dogma (Behnke et al. 2006; Martiny et al. 2006) because some populations appear to have global distributions (Finlay 2002;

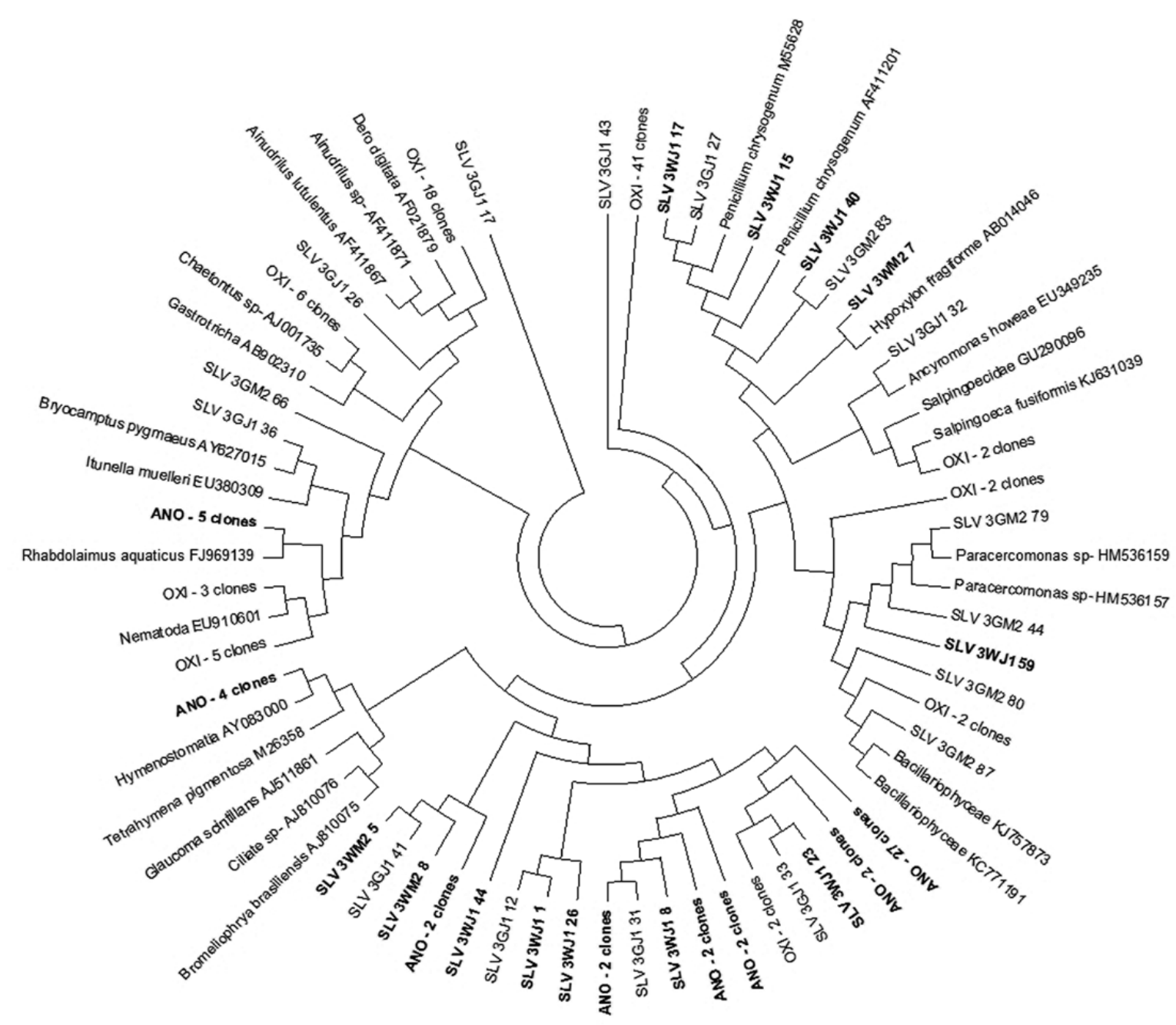

Fig. 5: Molecular phylogenetic analysis of eukaryotic $18 \mathrm{~S}$ rDNA by Maximum likelihood method. Clones for the white (W, also labelled in bold) and grey $(G)$ mats are included, and redox conditions for the mats are noted if more than one clone formed a clade, ANO for anoxic mats and OXI for oxic mats. The evolutionary history was inferred by using the Maximum Likelihood method based on the Kimura 2-parameter model (Kimura, 1980). The bootstrap consensus tree inferred from 100 replicates (Felsenstein, 1985) is taken to represent the evolutionary history of the taxa analysed (Felsenstein, 1985). Branches corresponding to partitions reproduced in less than $50 \%$ bootstrap replicates are collapsed. Initial tree(s) for the heuristic search were obtained by applying the neighbour joining method to a matrix of pairwise distances estimated using the Maximum Composite Likelihood (MCL) approach. The analysis involved 180 nucleotide sequences. All positions with less than 95\% site coverage were eliminated. That is, fewer than 5\% alignment gaps, missing data, and ambiguous bases were allowed at any position. There were a total of 1528 positions in the final dataset. 
Bass et al. 2007; Guillou et al. 2008). In general, spatial distributions of organisms within a habitat are influenced by feeding and grazing options and pressures within a food web (Sherr \& Sherr 1994; Sherr \& Sherr 2002; Pernthaler 2005; Orsi et al. 2011) and dispersal mechanisms (Richards \& Bass 2005), which relate strongly to organism size (Fenchel \& Finlay 1995; Finlay 2002; Soininen \& Heino 2007). Food web structure is also influenced by organism size, with bacteria and smaller protozoa serving as food for larger organisms, as well as the scale of the habitat and environmental extremes that could lead to specialized metabolisms, particularly in ecotonal habitats (Edgcomb et al. 2002; Griebler et al. 2014). However, interpretations regarding endemic versus cosmopolitan spatial occurrences of microeukaryotes may be premature because their diversity and ecology from many different habitats is generally understudied. Knowledge regarding microeukaryotes in karst systems is especially poor (Engel 2010).

Therefore, the purpose of our study was to evaluate microeukaryotic diversity from the undersampled environment of a karst spring. The Žveplenica karst water mean transit time of 1.0 to 1.5 years (Mulec et al. 2015) may be long enough to develop karst AMEC (Farnleitner et al. 2005; Pronk et al. 2009) that can be sampled at the spring. By studying the microbial mats at the spring, unique microeukaryotic diversity was uncovered that paved the way to study eukaryotic AMEC. Collectively, the implications of this study relate to community dynamics, such as grazing dynamics, in sulphidic to oxic ecotones and potential patterns in microbial phylogeography related to microeukaryote host dispersal mechanisms.

We chose the Žveplenica karst spring because results could be compared to those from previous studies in geochemically similar lakes and marine systems where diverse microeukaryotic groups occupy sulphidic to oxic ecotones (Edgcomb et al. 2002; Lopez-Garcia et al. 2003; Stoeck et al. 2003; Luo et al. 2005; Behnke et al. 2006; Zuendorf et al. 2006; Nold et al. 2010a; Nold et al. 2010b; Oikonomou et al. 2015). However, most of the gastrotrichs, ciliophora, cercomonads, and nematodes from the spring samples had $<95 \%$ sequence identity to previously described taxonomic groups. This implies a level of novelty for the Žveplenica spring microeukaryotes diversity. Conversely, and perhaps obviously, because this type of habitat is undersampled, lineage novelty may simply be due to a lack of information about these groups. Future research should attempt to address the level of endemism for the microeukaryotes retrieved from the Žveplenica karst spring to verify AMEC membership.

Ecologically important eukaryotic groups were retrieved from the spring that are known to be anaerobic and that occupy sulphidic to oxic ecotones, such as members of alveolates and fungi (Stoeck \& Epstein 2003). Limited overlapping taxonomic representation between the white and grey mats, and lower diversity in the white mats from the anoxic and sulphidic portion of the stream, suggested niche specialization. The specific microeukaryote ecology and potential niche occupation based on geochemistry may result in a less complex food web structure in the white mats, with fungi significant in cross-feeding, anaerobic ciliophora, and bacterivorous nematodes like Rhabdolaimus spp. Moreover, Cochlonema spp. are obligatory zoopagalean parasites of freeliving amoeba (Koehsler et al. 2007), although no sequences for amoeba were retrieved from the white mats. This corresponds to previous unsuccessful attempts to isolate amoebae.

In contrast, the diverse grey mat food web structure may be more complex because the mat was comprised of a mix of anaerobic and aerobic stramenopiles, alveolates, cercomonads, and fungi (Stoeck \& Epstein 2003), in addition to nematodes, sludge and round worms, gastrotrichs, copepods, and tardigrades that all participate in various trophic interactions as decomposers, predators, and parasites. In general, gastrotrichs are broadly distributed in aquatic habitats, typically are associated with sediments and benthic substrate, and consume bacteria and smaller protozoa as detritivores (Ricci \& Balsamo 2000).

Previously, six faunal groups were identified from the filtered sulphidic water through a container equipped with $60 \mu \mathrm{m}$ mesh, oligochaetes, crustaceans (Cladocera, Cyclopoida, and Harpacticoida), gastropods, and Trichoptera (Mulec et al. 2015). The impact of microeukaryotic grazing on microbial mats has been well established (Dalby et al. 2008; Takishita et al. 2010; Edgcomb \& Pachiadaki 2014), such that the types of bacteria and archaea that grow in a habitat need not only to tolerate the ecological conditions, but also to grow faster than grazing occurs. The presence of larger organisms, including flagellates and euglenids in the grey mats, may assist the dispersal of some bacteria during grazing, as previous evidence suggests that some Epsilonproteobacteria representative can survive and/or replicate within protozoa (Winiecka-Krusnell et al. 2002; Axelsson-Olsson et al. 2005).

In conclusion, the microbial mats occurring within the sulphidic to oxic ecotone of the Žveplenica spring are an important local biodiversity hotspot. Diverse bacteria and archaea associated with chemolithoautotrophy and primary productivity occupy the mats and serve as a rich food source for microeukaryotic heterotrophs that are likely sourced from the karst aquifer. Because of the sulphide-oxygen gradient, the microeukaryotic diversity of microbial mats is distinct between the anoxic versus oxygenated portion of the stream, such that the association 
of some microeukaryotes with the bacterial and archaeal diversity may be related to grazing options, in addition to ecological tolerance of the geochemical conditions. These results expand what is known of microeukaryotes in continental karst systems and ecotonal habitats
(Fenchel \& Finlay 1995; Dawson \& Pace 2002; Edgcomb et al. 2002; Stoeck et al. 2003; Luo et al. 2005; Behnke et al. 2006; Epstein \& Lopez-Garcia 2008; Behnke et al. 2010; Creer \& Sinniger 2012; Parris et al. 2014; Wang et al. 2014; Oikonomou et al. 2015).

\section{ACKNOWLEDGEMENTS}

This work was supported by the Slovenian Research Agency [J6-0152] and US National Science Foundation [DEB-0640835]. The authors acknowledge Mateja Zadel for laboratory support, and Kathleen M. Brannen-Don- nelly, Brendan M. Donnelly, Philip G. Bergeron, Kathryn G. Huber, Andreea Oarga-Mulec, Karen E. Rossmassler, and Barbara J. Campbell for field support.

\section{REFERENCES}

Adl, S.M., Simpson, A.G.B., Farmer, M.A., Andersen, R.A., Anderson, O.R., Barta, J.R., Bowser, S.S., Brugerolle, G., Fensome, R.A., Fredericq, S., James, T.Y., Karpov, S., Kugrens, P., Krug, J., Lane, C.E., Lewis, L.A., Lodge, J., Lynn, D.H., Mann, D.G., McCourt, R.M., Mendoza, L., Moestrup, O., Mozley-Standridge, S.E., Nerad, T.A., Shearer, C.A., Smirnov, A.V., Spiegel, F.W. \& M.F. Taylor, 2005: The new higher level classification of eukaryotes with emphasis on the taxonomy of protists.- Journal of Eukaryotic Microbiology, 52, 399-451. DOI: https:// doi.org/10.1111/j.1550-7408.2005.00053.x.

Anderson, R.E., Sogin, M.L. \& J.A. Baross, 2015: Biogeography and ecology of the rare and abundant microbial lineages in deep-sea hydrothermal vents.FEMS Microbiology Ecology, 91, 1-11. DOI: https:// doi.org/10.1093/femsec/fiu016.

Axelsson-Olsson, D., Waldenstrom, J., Broman, T., Olsen, B. \& M. Holmberg, 2005: Protozoan Acanthamoeba polyphaga as a potential reservoir for Campylobacter jejuni.- Applied and Environmental Microbiology, 71, 987-992. DOI: https://doi.org/10.1128/ aem.71.2.987-992.2005.

Baker, G.C. \& D.A. Cowan, 2004: 16 S rDNA primers and the unbiased assessment of thermophile diversity.Biochemical Society Transactions, 32, 218-221. DOI: https://doi.org/10.1042/bst0320218.

Bass, D., Richards, T., Matthai, L., Marsh, V. \& T. Cavalier-Smith, 2007: DNA evidence for global dispersal and probable endemicity of protozoa.- BMC Evolutionary Biology, 7, 162. DOI: https://doi. org/10.1186/1471-2148-7-162.
Behnke, A., Barger, K., Bunge, J. \& T. Stoeck, 2010: Spatio-temporal variations in protistan communities along an $\mathrm{O}_{2} / \mathrm{H}_{2} \mathrm{~S}$ gradient in the anoxic Framvaren Fjord (Norway).- FEMS Microbiology Ecology, 72, 89-102. DOI: https://doi.org/10.1111/j.15746941.2010.00836.x.

Behnke, A., Bunge, J., Barger, K., Breiner, H.W., Alla, V. \& T. Stoeck, 2006: Microeukaryote community patterns along an $\mathrm{O}_{2} / \mathrm{H}_{2} \mathrm{~S}$ gradient in a supersulfidic anoxic Fjord (Framvaren, Norway).- Applied and Environmental Microbiology, 72, 3626-3636. DOI: https://doi.org/10.1128/aem.72.5.36263636.2006.

Boenigk, J., Jost, S., Stoeck, T. \& T. Garstecki, 2007:Differential thermal adaptation of clonal strains of a protist morphospecies originating from different climatic zones.- Environmental Microbiology, 9, 593602. DOI: https://doi.org/10.1111/j.1462-2920. 2006.01175.x.

Borrel, G., Lehours, A., Bardot, C., Bailly, X. \& G. Fonty, 2010: Members of candidate divisions OP11, OD1 and SR1 are widespread along the water column of the meromictic Lake Pavin (France).- Archives of Microbiology, 192, 559-567. DOI: https://doi. org/10.1007/s00203-010-0578-4.

Brannen-Donnelly, K. \& A.S. Engel, 2015: Bacterial diversity differences along an epigenic cave stream reveal evidence of community dynamics, succession, and stability.- Front iers in Microbiology, 6, 729. DOI: https://doi.org/10.3389/ fmicb.2015.00729. 
Camacho, C., Coulouris, G., Avagyan, V., Ma, N., Papadopoulos, J., Bealer, K. \& T. Madden, 2009: BLAST+: architecture and applications.- BMC Bioinformatics, 10, 421. DOI: https://doi.org/10.1186/1471-2105-10-421.

Cole, J., Wang, Q., Fish, J., Chai, B., McGarrell, D., Sun, Y., Brown, C., Porras-Alfaro, A., Kuske, C. \& J. Tiedje, 2014: Ribosomal Database Project: data and tools for high throughput rRNA analysis.- Nucleic Acids Research, 42, D633-D642. DOI: https://doi. org/10.1093/nar/gkt1244.

Creer, S. \& F. Sinniger, 2012: Cosmopolitanism of microbial eukaryotes in the global deep seas.- Molecular Ecology, 21, 1033-1035. DOI: https://doi. org/10.1111/j.1365-294x.2012.05437.x.

Dalby, A., Kormas, K., Christaki, U. \& H. Karayanni, 2008: Cosmopolitan heterotrophic microeukaryotes are active bacterial grazers in experimental oil-polluted systems.- Environmental Microbiology, 10, 47-56. DOI: https://doi.org/10.1111/j.14622920.2007.01428.x.

Dawson, S. \& N. Pace, 2002: Novel kingdom-level eukaryotic diversity in anoxic environments. Proceedings of the National Academy of Sciences of the United States of America, 99, 8324-8329. DOI: https://doi. org/10.1073/pnas.062169599.

DeSantis, T.Z., Hugenholtz, P., Larsen, N., Rojas, M., Brodie, E.L., Keller, K., Huber, T., Dalevi, D., Hu, P. \& G.L. Andersen, 2006: Greengenes, a chimerachecked 16S rRNA gene database and workbench compatible with ARB.- Applied and Environmental Microbiology, 72, 5069-5072. DOI: https://doi. org/10.1128/aem.03006-05.

Diez, B., Pedros-Alio, C. \& R. Massana, 2001: Study of genetic diversity of eukaryotic picoplankton in different oceanic regions by small-subunit rRNA gene cloning and sequencing.- Applied and Environmental Microbiology, 67, 2932-2941. DOI: https://doi. org/10.1128/aem.67.7.2932-2941.2001.

Edgar, R., Haas, B., Clemente, J.C., Quince, C. \& R. Knight, 2011: UCHIME improves sensitivity and speed of chimera detection.- Bioinformatics, 27 2194-2200. DOI: https://doi.org/10.1093/bioinformatics/btr381.

Edgcomb, V. \& M. Pachiadaki, 2014: Ciliates along oxyclines of permanently stratified marine water columns.- Journal of Eukaryotic Microbiology, 61, 434-445. DOI: https://doi.org/10.1111/jeu.12122.

Edgcomb, V., Kysela, D., Teske, A., Gomez, A. \& M. Sogin, 2002: Benthic eukaryotic diversity in the Guaymas Basin hydrothermal vent environment.Proceedings of the National Academy of Sciences of the United States of America, 99, 7658-7662. DOI: https://doi.org/10.1073/pnas.062186399.
Elwood, H., Olsen, G. \& M. Sogin, 1985: The smallsubunit ribosomal RNA gene sequences from the hypotrichous ciliates Oxytricha nova and Stylonychia pustulata.- Molecular Biology and Evolution, 2, 399-410. DOI: https://doi.org/10.1093/oxfordjournals.molbev.a040362.

Engel, A.S., 2007: Observations on the biodiversity of sulfidic karst habitats.- Journal of Cave and Karst Studies, 69, 187-206.

Engel, A.S., Lee, N., Porter, M., Stern, L., Bennett, P. \& M. Wagner, 2003: Filamentous „Epsilonproteobacteria" dominate microbial mats from sulfidic cave springs.- Applied and Environmental Microbiology, 69, 5503-5511. DOI: https://doi.org/10.1128/ aem.69.9.5503-5511.2003.

Engel, A.S., 2010: Microbial diversity of cave ecosystems.- In: Loy, A. et al. (eds.) Geomicrobiology: Molecular and Environmental Perspective. Springer, pp. 219-238, Dordrecht, Heidelberg, London, New York. DOI: https://doi.org/10.1007/978-90-4819204-5_10.

Epstein, S. \& P. Lopez-Garcia, 2008: „Missing“ protists: a molecular prospective.- Biodiversity and Conservation, 17, 261-276. DOI: https://doi.org/10.1007/ s10531-007-9250-y.

Farnleitner, A., Wilhartitz, I., Ryzinska, G., Kirschner, A., Stadler, H., Burtscher, M., Hornek, R., Szewzyk, U., Herndl, G. \& R. Mach, 2005: Bacterial dynamics in spring water of alpine karst aquifers indicates the presence of stable autochthonous microbial endokarst communities.- Environmental Microbiology, 7, 1248-1259. DOI: https://doi.org/10.1111/j.14622920.2005.00810.x.

Felsenstein, J., 1985: Confidence limits on phylogenies: An approach using the bootstrap.- Evolution, 39, 783-791. DOI: https://doi.org/10.2307/2408678

Fenchel, T.M. \& B.J. Finlay, 1995: Ecology and Evolution in Anoxic Worlds.- Oxford University Press, pp. 288, Oxford.

Finlay, B., 2002: Global dispersal of free-living microbial eukaryote species.- Science, 296, 1061-1063. DOI: https://doi.org/10.1126/science.1070710.

Ford, D. \& P.W. Williams, 2007: Karst Hydrogeology and Geomorphology.- John Wiley, pp. 562, Chichester. DOI: https://doi.org/10.1002/9781118684986.

Gittleson, S. \& R. Hoover, 1969: Cavernicolous protozoa: review of the literature and new studies in Mammoth cave, Kentucky.- Annales de Spéléolgie, 24, 737-776.

Griebler, C. \& L. Lueders, 2009: Microbial biodiversity in groundwater ecosystems.- Freshwater Biology, 54, 649-677. DOI: https://doi.org/10.1111/j.13652427.2008.02013.x. 
Griebler, C., Malard, F. \& T. Lefébure, 2014: Current developments in groundwater ecology - from biodiversity to ecosystem function and services.- Current Opinion in Biotechnology, 27, 159-167. DOI: https://doi.org/10.1016/j.copbio.2014.01.018.

Guillou, L., Viprey, M., Chambouvet, A., Welsh, R., Kirkham, A., Massana, R., Scanlan, D. \& A. Worden, 2008: Widespread occurrence and genetic diversity of marine parasitoids belonging to Syndiniales (Alveolata).- Environmental Microbiology, 10, 3349-3365. DOI: https://doi.org/10.1111/ j.1462-2920.2008.01731.x.

Hamilton, T., Jones, D., Schaperdoth, I. \& J. Macalady, 2015: Metagenomic insights into $S(0)$ precipitation in a terrestrial subsurface lithoautotrophic ecosystem.- Frontiers in Microbiology, 5, 756, DOI: https://doi.org/10.3389/fmicb.2014.00756.

Heino, J. \& J. Soininen, 2006: Regional occupancy in unicellular eukaryotes: a reflection of niche breadth, habitat availability or size-related dispersal capacity?- Freshwater Biology, 51, 672-685. DOI: https:// doi.org/10.1111/j.1365-2427.2006.01520.x.

Holder, T., Basquin, C., Ebert, J., Randel, N., Jollivet, D., Conti, E., Jekely, G. \& F. Bono, 2013: Deep transcriptome-sequencing and proteome analysis of the hydrothermal vent annelid Alvinella pompejana identifies the CvP-bias as a robust measure of eukaryotic thermostability.- Biology Direct, 8, 2, DOI: https://doi.org/10.1186/1745-6150-8-2.

Kimura, M., 1980: A simple method for estimating evolutionary rates of base substitutions through comparative studies of nucleotide sequences.- Journal of Molecular Evolution, 16, 111-120. DOI: https:// doi.org/10.1007/bf01731581.

Koehsler, M., Walochnik, J., Michel, R., Lugauer, J. \& C. Wylezich, 2007: Molecular identification and classification of Cochlonema euryblastum, a zoopagalean parasite of Thecamoeba quadrilineata.- Mycologia, 99, 215-221. DOI: https://doi.org/10.3852/ mycologia.99.2.215.

Kolasa, J. \& M. Zalewski, 1995: Notes on ecotone attributes and functions.- Hydrobiologia, 303, 1-7. DOI: https://doi.org/10.1007/bf00034039.

Lane, D., 1991: 16S/23S rRNA sequencing.- In: Stackebrandt, E. \& M. Goodfellow (eds.) Nucleic Acid Techniques in Bacterial Systematics. Wiley, pp. 115-175, New York.

Latella, L., Di Russo, C., De Pasquale, L., Dell'Anna, L., Nardi, G. \& M. Rampini, 1999: Preliminary investigations on a new sulfurous cave in Central Italy.Mémoires de Biospéleolgie, 26, 131-135.

Lopez-Garcia, P., Rodriguez-Valera, F., Pedros-Alio, C. \& D. Moreira, 2001: Unexpected diversity of small eukaryotes in deep-sea Antarctic plankton.- Nature, 409, 603-607. DOI: https://doi. org/10.1038/35054537.

Lopez-Garcia, P., Philippe, H., Gail, F. \& D. Moreira, 2003: Autochthonous eukaryotic diversity in hydrothermal sediment and experimental microcolonizers at the Mid-Atlantic Ridge.- Proceedings of the National Academy of Sciences of the United States of America, 100, 697-702. DOI: https://doi. org/10.1073/pnas.0235779100.

Luo, Q., Krumholz, L., Najar, F., Peacock, A., Roe, B., White, D. \& M. Elshahed, 2005: Diversity of the microeukaryotic community in sulfide-rich zodletone spring (Oklahoma).- Applied and Environmental Microbiology, 71, 6175-6184. DOI: https:// doi.org/10.1128/aem.71.10.6175-6184.2005.

Maggi, O., Di Russo, C., Latella, L., Raffaelli, G. \& M. Rampini, 2002: The fungal communities of the Fiume Coperto sulfurous cave waters.- In: Latella, L. et al. (eds) Abstracts of the $16^{\text {th }}$ International Symposium of Biospeleology. 8th-15th September 2002, Verona, Societé Internationale de Biospéologie, 82-83, Verona.

Martiny, J., Bohannan, B., Brown, J., Colwell, R., Fuhrman, J., Green, J., Horner-Devine, M., Kane, M., Krumins, J., Kuske, C., Morin, P., Naeem, S., Ovreas, L., Reysenbach, A., Smith, V. \& J. Staley, 2006: Microbial biogeography: putting microorganisms on the map.- Nature Reviews Microbiology, 4, 102112. DOI: https://doi.org/10.1038/nrmicro1341.

Mattes, T., Nunn, B., Marshall, K., Proskurowski, G., Kelley, D., Kawka, O., Goodlett, D., Hansell, D. \& R. Morris, 2013: Sulfur oxidizers dominate carbon fixation at a biogeochemical hot spot in the dark ocean.- ISME Journal, 7, 2349-2360. DOI: https:// doi.org/10.1038/ismej.2013.113.

Mulec, J., Oarga, A., Schiller, E., Perşoiu, A., Holko, L. \& S. Šebela, 2015: Assessment of the physical environment of epigean invertebrates in a unique habitat: the case of a karst sulfidic spring, Slovenia.- Ecohydrology, 8, 1326-1334. DOI: https:// doi.org/10.1002/eco.1585.

Nold, S., Pangborn, J., Zajack, H., Kendall, S., Rediske, R. \& B. Biddanda, 2010a: Benthic bacterial diversity in submerged sinkhole ecosystems.- Applied and Environmental Microbiology, 76, 347-351. DOI: https://doi.org/10.1128/aem.01186-09.

Nold, S., Zajack, H. \& B. Biddanda, 2010b: Eukaryal and archaeal diversity in a submerged sinkhole ecosystem influenced by sulfur-rich, hypoxic groundwater.- Journal of Great Lakes Research, 36, 366-375. DOI: https://doi.org/10.1016/j. jglr.2010.02.014. 
Offre, P., Spang, A., \& C. Schleper, 2013: Archaea in biogeochemical cycles.- Annual Review of Microbiology, 67, 437-457. DOI: https://doi.org/10.1146/annurevmicro-092412-155614.

Oikonomou, A., Filker, S., Breiner, H.W. \& T. Stoeck, 2015: Protistan diversity in a permanently stratified meromictic lake (Lake Alatsee, SW Germany).- Environmental Microbiology, 6, 2144-2157. DOI: https://doi. org/10.1111/1462-2920.12666.

Orsi, W., Edgcomb, V., Jeon, S., Leslin, C., Bunge, J., Taylor, G., Varela, R. \& S. Epstein, 2011: Protistan microbial observatory in the Cariaco Basin, Caribbean. II. Habitat specialization.- ISME Journal, 5, 1357-1373. DOI: https://doi.org/10.1038/ismej.2011.7.

Parris, D., Ganesh, S., Edgcomb, V., DeLong, E. \& F. Stewart, 2014: Microbial eukaryote diversity in the marine oxygen minimum zone off northern Chile.- Frontiers in Microbiology, 5, 543, DOI: https://doi.org/10.3389/ fmicb.2014.00543.

Pernthaler, J., 2005: Predation on prokaryotes in the water column and its ecological implications.- Nature Reviews Microbiology, 3, 537-546. DOI: https://doi. org/10.1038/nrmicro1180.

Por, F.D., Dimentman, C., Frumkin, A. \& I. Naaman, 2013: Animal life in the chemoautotrophic ecosystem of the hypogenic groundwater cave of Ayyalon (Israel): A summing up.- Natural Science, 5, 7-13. DOI: https:// doi.org/10.4236/ns.2013.54a002.

Porter, M., Engel, A., Kane, T. \& B. Kinkle, 2009: Productivity-diversity relationships from chemolithoautotrophically based sulfidic karst systems.- International Journal of Speleology, 38, 27-40. DOI: https://doi. org/10.5038/1827-806x.38.1.4.

Pronk, M., Goldscheider, N. \& J. Zopfi, 2009: Microbial communities in karst groundwater and their potential use for biomonitoring.- Hydrogeology Journal, 17, 37 48. DOI: https://doi.org/10.1007/s10040-008-0350-x.

Pruesse, E., Peplies, J. \& F. Glöckner, 2012: SINA: Accurate high-throughput multiple sequence alignment of ribosomal RNA genes.- Bioinformatics, 28- 1823-1829. DOI: https://doi.org/10.1093/bioinformatics/bts252.

Pruesse, E., Quast, C., Knittel, K., Fuchs, B.M., Ludwig, W., Peplies, J. \& F.O. Glöckner, 2007: SILVA: a comprehensive online resource for quality checked and aligned ribosomal RNA sequence data compatible with ARB.- Nucleic Acids Research, 35, 7188-7196. DOI: https://doi.org/10.1093/nar/gkm864.

Quast, C., Pruesse, E., Yilmaz, P., Gerken, J., Schweer, T., Yarza, P., Peplies, J. \& F. Glöckner, 2013: The SILVA ribosomal RNA gene database project: improved data processing and web-based tools.- Nucleic Acids Research, 41, D590-D596. DOI: https://doi. org/10.1093/nar/gks1219.
Ricci, C. \& M. Balsamo, 2000: The biology and ecology of lotic rotifers and gastrotrichs.- Freshwater Biology, 44, 15-28. DOI: https://doi.org/10.1046/j.13652427.2000.00584.x.

Richards, T. \& D. Bass, 2005: Molecular screening of free-living microbial eukaryotes: diversity and distribution using a meta-analysis.- Current Opinion in Microbiology, 8, 240-252. DOI: https://doi. org/10.1016/j.mib.2005.04.010.

Rossmassler, K., Engel, A.S., Twing, K., Hanson, T. \& B. Campbell, 2012: Drivers of epsilonproteobacterial community composition in sulfidic caves and springs. FEMS Microbiology Ecology, 79, 421-432. DOI: https://doi.org/10.1111/j.15746941.2011.01231.x.

Sarbu, S.M., 1990: The unusual fauna of a cave with thermomineral waters containing $\mathrm{H}_{2} \mathrm{~S}$ from Southern Dobrogea, Romania.- Mémoires de Biospéleologie, 17, 191-195.

Schloss, P.D., Westcott, S.L., Ryabin, T., Hall, J.R., Hartmann, M., Hollister, E.B., Lesniewski, R.A., Oakley, B.B., Parks, D.H., Robinson, C.J., Sahl, J.W., Stres, B., Thallinger, G.G., Van Horn, D.J. \& C.F. Weber, 2009: Introducing mothur: open-source, platformindependent, community-supported software for describing and comparing microbial communities.- Applied and Environmental Microbiology, 75, 7537-7541. DOI: https://doi.org/10.1128/ aem.01541-09.

Sherr, E. \& B. Sherr, 1994: Bacterivory and herbivory key roles of phagotrophic protists in pelagic food webs.- Microbial Ecology, 28, 223-235. DOI: https://doi.org/10.1007/bf00166812.

Sherr, E. \& B. Sherr, 2002: Significance of predation by protists in aquatic microbial food webs.- Antonie van Leeuwenhoek International Journal of General and Molecular Microbiology, 81, 293-308.

Sigala-Regalado, I., Mayen-Estrada, R. \& J. MoralesMalacara, 2011: Spatial and temporal distribution of protozoa at Cueva de los Riscos, Querétaro, México.- Journal of Cave Karst Studies, 73, 55-62. DOI: https://doi.org/10.4311/jcks2009mb121.

Skirnisdottir, S., Hreggvidsson, G., Hjorleifsdottir, S., Marteinsson, V., Petursdottir, S., Holst, O. \& J. Kristjansson, 2000: Influence of sulfide and temperature on species composition and community structure of hot spring microbial mats.- Applied and Environmental Microbiology, 66, 2835-2841. DOI: https://doi.org/10.1128/aem.66.7.2835-2841.2000.

Soininen, J. \& J. Heino, 2007: Variation in niche parameters along the diversity gradient of unicellular eukaryote assemblages.- Protist, 158, 181-191. DOI: https://doi.org/10.1016/j.protis.2006.11.002. 
Stoeck, T. \& S. Epstein, 2003: Novel eukaryotic lineages inferred from small-subunit rRNA analyses of oxygen-depleted marine environments.- Applied and Environmental Microbiology, 69, 2657-2663. DOI: https://doi.org/10.1128/aem.69.5.2657-2663.2003.

Stoeck, T., Taylor, G. \& S. Epstein, 2003: Novel eukaryotes from the permanently anoxic Cariaco Basin (Caribbean sea).- Applied and Environmental Microbiology, 69, 5656-5663. DOI: https://doi.org/10.1128/ aem.69.9.5656-5663.2003.

Tahseen, Q., 2012: Nematodes in aquatic environments: adaptations and survival strategies.- Biodiversity Journal, 3, 13-40.

Takai, K., Gamo, T., Tsunogai, U., Nakayama, N., Hirayama, H., Nealson, K. \& K. Horikoshi, 2004: Geochemical and microbiological evidence for a hydrogen-based, hyperthermophilic subsurface lithoautotrophic microbial ecosystem (HyperSLiME) beneath an active deep-sea hydrothermal field.- Extremophiles, 8, 269-282. DOI: https://doi. org/10.1007/s00792-004-0386-3.

Takishita, K., Kakizoe, N., Yoshida, T. \& T. Maruyama, 2010: Molecular evidence that phylogenetically diverged ciliates are active in microbial mats of deepsea cold-seep sediment.- Journal of Eukaryotic Microbiology, 57, 76-86. DOI: https://doi.org/10.1111/ j.1550-7408.2009.00457.x.

Tamura, K., Stecher, G., Peterson, D., Filipski, A. \& S. Kumar, 2013: MEGA6: Molecular evolutionary genetics analysis version 6.0.- Molecular Biology and Evolution, 30, 2725-2729. DOI: https://doi. org $/ 10.1093 / \mathrm{molbev} / \mathrm{mst} 197$.

Thompson, D.B. \& R.A. Olson, 1988: A preliminary survey of the protozoa and bacteria from Sulphur River, in Parker's Cave, Kentucky.- Bulletin of the National Speleological Society, 50, 42-46.
Walochnik, J. \& J. Mulec, 2009: Free-living amoebae in carbonate precipitating microhabitats of karst caves and a new vahlkampfiid amoeba, Allovahlkampfia spelaea gen. nov., sp nov.- Acta Protozoologica, 48, 25-33.

Wang, Y., Zhang, W., Cao, H., Shek, C., Tian, R., Wong, Y., Batang, Z., Al-Suwailem, A. \& P. Qian, 2014: Diversity and distribution of eukaryotic microbes in and around a brine pool adjacent to the Thuwal cold seeps in the Red Sea.- Frontiers in Microbiology, 5, 37. DOI: https://doi.org/10.3389/fmicb.2014.00037.

Winiecka-Krusnell, J., Wreiber, K., Von Euler, A., Engstrand, L. \& E. Linder, 2002: Free-living amoebae promote growth and survival of Helicobacter pylori.- Scandinavian Journal of Infectious Diseases, 34, 253-256. DOI: https://doi. org/10.1080/00365540110080052.

Wright, E., Yilmaz, L. \& D. Noguera, 2012: DECIPHER, a Search-Based Approach to Chimera Identification for $16 \mathrm{~S}$ rRNA Sequences.- Applied and Environmental Microbiology, 78, 717-725. DOI: https://doi. org/10.1128/aem.06516-11.

Zega, M., Rožič, B., Gaberšek, M., Kanduč, T., Rožič, P. \& T. Verbovšek, 2015: Mineralogical, hydrogeochemical and isotopic characteristics of the Žveplenica sulphide karstic spring (Trebuša Valley, NW Slovenia).- Environmental Earth Sciences, 74, 3287-3300. DOI: https://doi.org/10.1007/s12665-015-4357-z.

Zuendorf, A., Bunge, J., Behnke, A., Barger. K., Stoeck Zuendorf, A., Bunge, J., Behnke, A., Barger, K., Stoeck, T., 2006: Diversity estimates of microeukaryotes below the chemocline of the anoxic Mariager Fjord, Denmark.- FEMS Microbioloty Ecology, 58, 476-491. DOI: https://doi.org/10.1111/j.15746941.2006.00171.x. 